\title{
Analysis Of Internal And External Factors Related To The K4-Coverage Of Village Midwives In The Working Area Of Banjar District Health Department
}

Winda Maolinda ${ }^{1}$

${ }^{1}$ Master of Midwifery Program Faculty of Medicine, Padjadjaran University

maolindawinda@gmail.com

Tita Husnitawati Madjid ${ }^{2}$

${ }^{2}$ Departement of Obstetrics and Gynecology Faculty of Medicine, Padjajaran University

thmchoesog@yahoo.com

Hadi Susiarno

${ }^{3}$ Head of Midwifery Master's Program Faculty of Medicine Padjadjaran University

drhadisusiarno@yahoo.com

Herry Herman ${ }^{4}$

${ }^{4}$ Department of Orthopedics \& Traumatology Faculty of Medicine, Padjadjaran University

Herry_herman@yahoo.com

Ponpon S. Idjradinata ${ }^{5}$

${ }^{5}$ Department of Pediatrics Faculty of Medicine Universitas Padjadjaran

Ponpon.idjradinata25@gmail.com

Dewi Marhaeni Diah Herawati ${ }^{6}$

${ }^{6}$ Department of Public Health Faculty of Medicine, Padjadjaran University.

dewimdh@yahoo.com

\begin{abstract}
Objective: to know the relationship of internal factors (knowledge, skills, motivation, and workload) and external factors (leadership, procedure, facility, and supervision) with K4 coverage of village midwives in the working area of Banjar District Health Department.
\end{abstract}

Method: This research is an observational analytic study with cross sectional approach. Questionnaires and checklists were collected from 135 village midwives whose samples were taken by stratified random sampling technique in 15 sub-districts to determine factors related to achievement of K4 coverage in the Banjar District Health Department. Processing and data analysis using univariate analysis, chi square analysis and logistic regression analysis.

Result: The result of univariable analysis are good for knowledge and motivation with 41,5\% and $54,1 \%$. Skilled and moderate workloads of $60 \%$ and $41.5 \%$. Non-compliance with the procedure (SOP) of $51.1 \%$. While the leadership and supervision performed by midwife coordinator from health center and health department is less than 56,3\% and 53,3\%, supported by complete facility $63 \%$ from low $\mathrm{K} 4$ coverage achievement is $60 \%$. The result of Chi-Square analysis shows that there are correlation between internal factors (knowledge, skill, motivation, and workload), external factors (leadership, procedure, facility and supervision) with $\mathrm{K} 4$ coverage of $\mathrm{p}$ value $<0,05$. The result of logistic regression test of external factor is the most dominant variable is the procedure ( $p$ value $=0.001)$, the strength of the relationship can be seen from the value of Exp (B) that is the procedure with the achievement of $\mathrm{K} 4$ coverage $(\mathrm{OR}=33,34)$. For internal factor is knowledge $(\mathrm{p}$ value $=0,020)$, strength of relation can be seen from value $\operatorname{Exp}(\mathrm{B})$ that is procedure with achievement of $\mathrm{K} 4$ coverage $(\mathrm{OR}=4,918)$.

Conclusion: this research is internal and external factor in village midwife related to achievement of $\mathrm{K} 4$ coverage that obedience to SOP is a priority which must be overcome so that policy need to treat SOP and coaching / refreshing to increase knowledge in all Puskesmas Kabupaten Banjar.

Keywords: facility, Internal factors knowledge, K4 coverage, leadership, motivation, skill, workload. 


\section{INTRODUCTION}

Maternal and child health issues are one of the major health problems currently occurring in the State of Indonesia. Every hour a woman dies due to childbirth or is related to pregnancy [1]. To date there have been many health development programs in Indonesia aimed at addressing maternal and child health issues [2]. One of the health programs that became the key strategy of service provider health in an effort to improve the coverage of Maternal and Child Health $(\mathrm{MCH})$ that can have implications on Mortality Rate (AKI), namely antenatal care (ANC) [3]. According to WHO, maternal mortality cases between $33-50 \%$ are closely related to the low level of health services obtained during pregnancy [4].

Indicators used to describe maternal access to antenatal care are the first visit (K1 coverage) and fourth visit (K4 coverage) with health personnel with midwifery competence. Implementation of ANC services has been strengthened by the issuance of the Minister of Health policy set forth in Article 6 paragraph 1 letter b Permenkes 25 year 2014 on child health efforts one of which stated that the fetal health services in the womb are carried out through an integrated ANC examination on pregnant women and the service is performed regularly according to the standard that is at least 4 (four) times during pregnancy (once in trimester I, once in the second trimester and twice in the third trimester) [5].
Village midwives are midwives who are placed, required to stay and serve in the village to serve the community in achieving the target of health degree in their work area which includes one to two villages, in carrying out medical service duties both within and outside working hours the midwife must remain directly responsible to head of Puskesmas and cooperate with village apparatus [6].

The low coverage of K4 coverage or the mother who has an opportunity. 5 check is due to internal and external factors of the village midwife to perform ANC services. Internal factors are factors associated with the characteristics of a person, among others, knowledge, skills, motivation and, workload. While external factors (situasional) are factors that affect the performance of someone who comes from the environment include leadership, facilities, procedures, and supervision [7].

The preliminary survey conducted in January 2016 in one District of Banjar, East Martapura District, K4 coverage in 2016 was $59.3 \%$, and $75 \%$ of the village midwives said that most pregnant women did the examination only at the beginning of pregnancy and came back at the time will be maternity. Midwives have made counseling efforts to increase the frequency of patient visits, but most pregnant women do not follow midwife recommendations [8]. 


\section{RESEARCH METHODS}

This research method is analytic observasional, with approach of cross sectional which is done to all village midwife which is in working area of Health Service of Regency of banjar. The sampling technique using stratified random sampling in quota in layers in March-June 2017. In Kabupaten Banjar there are 20 districts, in this study researchers took 15 districts because 5 districts are again constrained by geographical access that is difficult to reach. Sample size based on calculation formula above is 90 , for the sake of analysis of sample size in rasch modeling based on calibration of stable aitem in \pm 0.5 logit with $95 \%$ confidence level of sample range 64 to 144 , on that consideration then the researcher determine the number of sample to 135 obtained from 15 sub-districts in Banjar district, each sub-district was collected by 9 random midwives. 3 So, the sample to be included in the research is 135.10 The inclusion criteria in this study are the village midwife who work> 1 year in the work area of Dinas Kesehatan, Village midwives who are educated in midwifery D3, Village midwives who are willing to sign the approval sheet become respondents, and village midwives who live in villages. The exclusion criteria in this study is if one fulfills one of the following criteria: Village midwife on leave or in a state of illness at the time of the study and Village midwife who has no book of record and reporting.

Data used in this research are primary data and secondary data. Primary data were collected using questionnaires on knowledge, motivation, workload, leadership, and supervision. Skills and procedures using checklists. Secondary data are K4 coverage data obtained from recording and reporting conducted by village midwife. Questionnaires developed by the researchers themselves refer to existing references, therefore tested the validity and reliability.

\section{RESULTS}

Respondent in this research is village midwife amount 135 people doing service coverage K4. The description of the subject in this study can be seen in table 1:

Table 1. Descriptive Data Characteristics of Respondents

\begin{tabular}{lcccc}
\hline & \multirow{2}{*}{ Variable } & \multicolumn{2}{c}{ Coverage } & \multirow{2}{*}{ Value $\mathrm{p}^{*}$} \\
\cline { 3 - 4 } & & High & Low & \\
\hline \multirow{2}{*}{ Age } & $\leq 26$ & 46 & 45 & \multirow{2}{*}{0,494} \\
\multirow{2}{*}{ Working } & $>26$ & 25 & 19 & \\
period & $1-<5$ & 35 & 29 & \multirow{2}{*}{0,444} \\
& $5-10$ & 22 & 26 & \\
\hline
\end{tabular}

*Test Chi Square 
Based on Table 1, the characteristics of age and work period in both groups of high and low K4 coverage did not show any significant difference $(\mathrm{P}>0.05)$. So the characteristics of respondents are homogeneous.

Table 2. Frequency Distribution of Internal and External Factors

\begin{tabular}{|c|c|c|c|}
\hline \multicolumn{2}{|c|}{ Variable } & $\mathrm{n}$ & $\%$ \\
\hline \multirow[t]{3}{*}{ Knowledge } & Good & 56 & 41,5 \\
\hline & Midle & 54 & 40,0 \\
\hline & Low & 25 & 18,5 \\
\hline \multirow[t]{2}{*}{ Motivation } & Good & 73 & 54,1 \\
\hline & Less & 62 & 45,9 \\
\hline \multirow[t]{2}{*}{ Skills } & skilled & 81 & 60,0 \\
\hline & Not skilled & 54 & 40,0 \\
\hline \multirow[t]{3}{*}{ Workload } & mild & 42 & 31,1 \\
\hline & moderate & 56 & 41,5 \\
\hline & severe & 37 & 27,4 \\
\hline \multirow[t]{2}{*}{ Leadership } & Good & 59 & 43,7 \\
\hline & Less & 76 & 56,3 \\
\hline \multirow[t]{2}{*}{ Procedure } & appropriate & 66 & 48,9 \\
\hline & Not appropriate & 69 & 51,1 \\
\hline \multirow[t]{2}{*}{ Facilities } & complete & 85 & 63 \\
\hline & incomplete & 50 & 37 \\
\hline \multirow[t]{2}{*}{ Supervition } & Good & 63 & 46,7 \\
\hline & Less & 72 & 53,3 \\
\hline \multirow[t]{2}{*}{ Coverege of $\mathrm{K} 4$} & High & 54 & 40 \\
\hline & Low & 81 & 60 \\
\hline
\end{tabular}

Based on table 2 it is found that most of the knowledge of midwives is good as much as $41.5 \%$, good midwife motivation as much as $54.1 \%$, skilled midwives as much as $60 \%$, work load perceived by midwives as much as
41.5\%. while for leadership variable mostly less as much 56,3\%, unsuitable procedure counted $51,1 \%$, complete facility $63 \%$, supervision less as much as $53,3 \%$ and, low $\mathrm{K} 4$ coverage as much as $60 \%$. 
Table 3. Relationship of Internal Factors with Achievement of K4 Coverage

\begin{tabular}{llccc}
\hline \multirow{2}{*}{ Variable } & \multicolumn{2}{c}{ Coverage } & \multirow{2}{*}{ Value p* } \\
\cline { 2 - 4 } Knowledge & Good & 33 & How & \\
& Middle & 15 & 39 & $<0,001$ \\
& Less & 5 & 20 & \\
Motivation & good & 39 & 34 & $<0,001$ \\
& Less & 14 & 48 & \\
Skill & Good & 43 & 38 & $<0,001$ \\
\multirow{3}{*}{ Workload } & Less & 10 & 44 & \\
& mild & 22 & 20 & 0,019 \\
& moderate & 23 & 33 & \\
\hline
\end{tabular}

* Chi-square Test

Based on table 3 can be seen there probability value obtained is smaller is a meaningful relationship between than the specified significance level ( $p$ knowledge, motivation, skills and, <0.05).

workload with coverage K4. The

The following map can be presented Wright midwives motivation with the achievement of K4 coverage, namely:

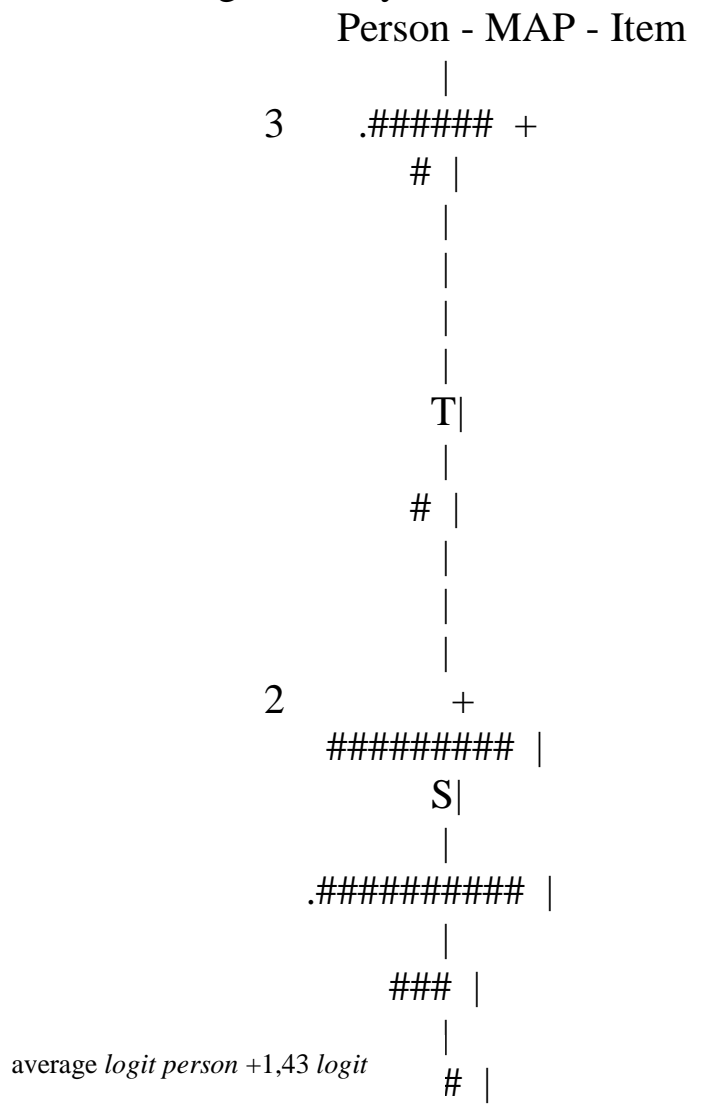




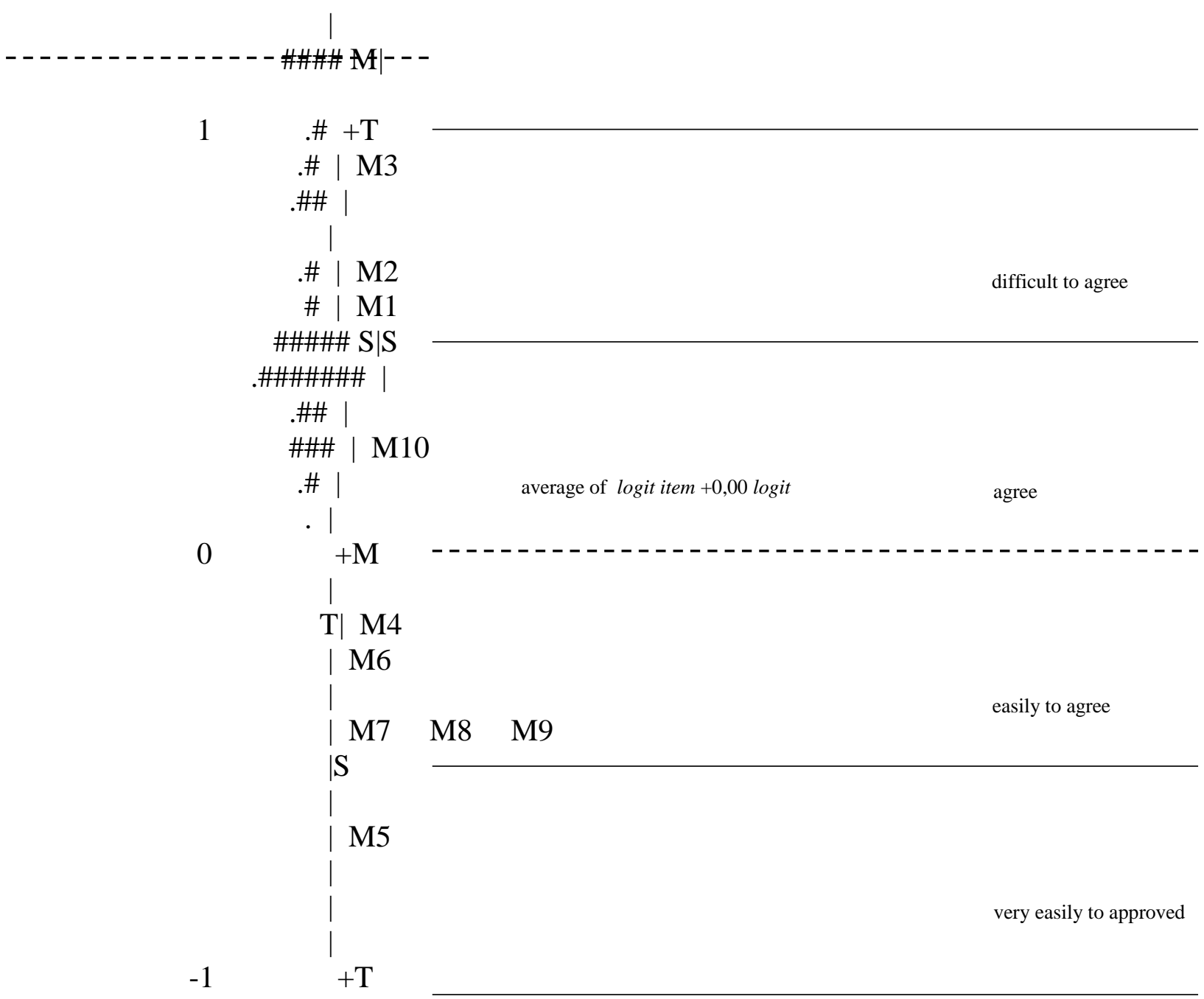

Figure 1 Wright Motivation Map Distribution

Based on the distribution of Wright map above shows that the left column is the person's column (respondent), the left column is the item column (statement). In the above map distribution it is known that the average logit person $(+1.43$ logit $)$ is higher than the average logit value of the item (+0.00 logit), with the percentage value $(100 \%)$. These results indicate that the average person's approval rate is higher than the average difficulty level item. It can be concluded that midwives have good motivation in providing $\mathrm{K} 4$ services in district of Banjar. 
Table 4. Relationship of External Factors with Achievement of K4 Coverage

\begin{tabular}{|c|c|c|c|c|}
\hline \multirow{2}{*}{\multicolumn{2}{|c|}{ Variable }} & \multicolumn{2}{|c|}{ Coverage } & \multirow[t]{2}{*}{ Value $\mathrm{p}^{*}$} \\
\hline & & High & Low & \\
\hline \multirow[t]{2}{*}{ Leadership } & Good & 29 & 30 & \multirow{2}{*}{0,038} \\
\hline & Kurang & 24 & 52 & \\
\hline \multirow[t]{2}{*}{ Procedure } & appropriate & 37 & 29 & \multirow{2}{*}{$<0,0001$} \\
\hline & Not appropriate & 16 & 53 & \\
\hline \multirow[t]{2}{*}{ Facilities } & complete & 43 & 42 & \multirow{2}{*}{$<0,0001$} \\
\hline & incomplete & 10 & 40 & \\
\hline \multirow[t]{2}{*}{ Supervition } & good & 32 & 31 & \multirow{2}{*}{0,010} \\
\hline & less & 21 & 51 & \\
\hline
\end{tabular}

* Chi-square test

Based on table 4 can be seen there is a meaningful relationship between leadership, procedures, facilities and, supervision with coverage K4. The probability value obtained is smaller than the specified significance level $(\mathrm{p}$ $<0.05)$.

Table 5. Factors Most Associated with Achievement of K4 Coverage

\begin{tabular}{lcccc}
\hline \multicolumn{1}{c}{ Variable } & $\mathrm{B}$ & $\mathrm{SE}(\beta)$ & $\mathrm{p}$ & OR $(\mathrm{IK} 95 \%)$ \\
\hline Knowledge & 1,593 & 0,687 & 0,020 & $4,918(1,280-18,89)$ \\
Skill & 1,449 & 0,513 & 0,005 & $4,260(1,558-11,64)$ \\
Procedure & 3,507 & 1,067 & 0,001 & $33,34(4,122-269,7)$ \\
Leadership & $-3,399$ & 1,072 & 0,002 & $0,033(0,004-0,273)$ \\
Supervition & 1,299 & 0,480 & 0,007 & $3,667(1,433-9,387)$ \\
\hline
\end{tabular}

Based on table 5. above, it can be seen that the results of the logistics analysis of the most related variables after analyzed collectively, namely the variables of knowledge, skills, procedures, leadership and supervision. Then look the procedure variable in this research most related to achievement of K4 coverage. The result of logistic regression test of procedure variable ( $p$ $=0,001)$ and $(\mathrm{IK}=4,122-269,7)$. The strength of the relationship can be seen from the value of OR (EXP1). The biggest and smallest strengths are the procedure $(\mathrm{OR}=33,34)$ and the leadership ( $O R=0,033)$. The equations obtained to predict the probability of achieving high $\mathrm{K} 4$ coverage are:

$\mathrm{y}=-3,012+1,593(1)+1,449(1)+$ $3,507(1)+(-3,399)(1)+1,299(1)$

$\mathrm{y}=1,437$

The probability is : $\mathrm{P}=1 /(1+\exp (1,437))$ $=0,19$. Thus, the probability of achieving high K4 coverage is $19 \%$.

The equations obtained to predict the probability of achieving low K4 coverage are: $\mathrm{y}=-3,012+1,593(0)+$ $1,449(0)+3,507(0)+(-3,399)(0)+$ $1,299(0) \mathrm{y}=-3,012$

The probability is : $\mathrm{P}=1 /(1+\exp (-$ $3,012))=0,95$. Thus, the probability of achieving high $\mathrm{K} 4$ coverage is $95 \%$. 


\section{DISCUSSION}

The average age of respondents is 27 years. The early adult age indicates that a person begins to organize his life, which has been revealed by Potter and Perry that early adulthood must have responsibility for achieving stability in work so that age can affect internal and external factors in the village midwife in achieving $\mathrm{K} 4$ coverage .11

The working period of the village midwife $47.4 \%$ has been working for $1-<5$ years. A person's working period needs to be known because it can be an indicator of workers' trends. Working period associated with work productivity, the longer a person works the higher the productivity, because it will be more experienced in completing the task entrusted him [12].

\section{a. Internal Factor}

Knowledge is an important domain for the formation of one's actions. Behavior based on knowledge will be long lasting rather than behavior that is not based on knowledge. In addition knowledge is also an early stage in the adoption of new behaviors before the formation of attitudes toward new objects that it faces. Knowledge is the result of knowing and this happens after people have sensed a particular object [13].

Skill is the ability of a person in doing something, as the communication process of learning to change a person's behavior becomes sticky, fast and precise, this skilled behavior is required in human life skills in the community with a person's skills in doing things in the form of tasks or jobs that use the body or work tools available. Skill is also the ability to hold non-verbal communication, which can convey messages through advance movement, hand movement, appearance and creative expression [14].

Any work in any field other than requiring personal ability or skill also requires sufficient motivation in one's self, so that the work done can be as successful as possible, in accordance with the theory of Notoatmodjo theory that, motivation or motive is an impulse from within someone who causes the person to perform certain activities in order to achieve a goal. Motives can not be observed, which can be observed is the activity or perhaps the reasons for such action [15].

According to the Ministry of Health, in general the proportion between the number of personnel and the number of programs in health services is not balanced so that a health worker can have more than one task. There is still a midwife workload that exceeds the standard of working hours affecting the performance of midwives who are not optimal in performing the role and function of the midwife as appropriate [16].

\section{b. External Factor}

A good leader is able to move and direct his subordinates to the achievement of the vision and mission of an organization. Triyantoro Safaria defines the leader as someone who occupies a central role or dominant position and influence in one group. In the concept of leadership, the most 
important element is the role, key, dominance and influence. Leadership will mean that if there is a balance, if he is in a group acceptable and internalized or in other words, one's leadership will be seen if there is a group of people he moves, directed to a common goal by accepting the legitimacy of a leader's presence that can enhance team work [17].

Working facilities is one of the supporting tools for a person in carrying out his duties, without a good work facility then a person can not work optimally. This research is in line with research conducted by Riyani stating that there is a relation between work facility and midwife performance on antenatal care service [18].

The quality of antenatal care service in this study is seen from the result of operational procedure standard (SOP) of K4 examination implementation, pregnancy examination is a way to obtain objective data which will be used to formulate the problem according to the condition of pregnant mother. If the examination is incomplete then the data obtained is less accurate, so the midwife will be difficult to analyze a problem [19].

Supervision is the same as supervision in the purpose of improving and improving performance, functioning as monitoring, its activities have management function and orientation to the purpose of organizing. This will help in monitoring the performance of a midwife. Unworkable supervision will lead to unmanageable subordinate performance resulting in unsuitable work results compared to assigned tasks. This is supported by Timpel's opinion that supervision is one of the external factors affecting performance [20].

c. The Most Influential Factors Affect Against K4 Coverage of Village Midwives in the Work Area of the District Health Office Banjar

Pregnancy check is a way to obtain objective data that will be used to formulate the problem in accordance with the circumstances of pregnant women. If the examination is incomplete then the data obtained is less accurate, so the midwife will be difficult to analyze a problem.96 Pregnancy checks performed in accordance with the procedure will be able to find out or explore the problems faced by pregnant women, so the risk or complication early will known.

The midwifery service procedure is useful in applying the norm and the level of performance required to achieve the desired outcome. Implementation of service standards will also protect the community, because assessment of the process and assessment results can be done on a clear basis. Measures the level of need for a good standard of input, service processes and service outcomes particularly the level of patient knowledge of antenatal care services known quality standards. Implementation of the standard of midwifery services in the practice of pregnancy examination indirectly can provide satisfactory service. Satisfactory service will result in customer loyalty.

Thus the researcher believes that the better service can be supported 
on standardized SOPs on the ANC. In the case of this study the implementation of the pregnancy screening procedure is an incentive for the midwife to increase $\mathrm{K} 4$ visits in the examination of pregnant women, we can see here that the implementation of the ANC procedure on $\mathrm{K} 4$ visit by the midwife is in an inappropriate category so it can be attributed that

\section{REFERENCES}

[1].Unicef Indonesia. Ringkasan Kajian Kesehatan Ibu dan anak. 2012. Tersedia dalam : https://www.unicef.org/indonesi $\underline{\mathrm{a} / \mathrm{id}}$ [Diunduh tanggal : 05 Agustus 2017].

[2].Adhetia Trisna. Praktik Perawatan Masa Nifas Di Kecamatan Pecangaan Kabupaten Jepara Terkait Dengan Faktor Sosial Budaya. 2016. Tersedia dalam: eprints.ums.ac.id/44705.

[Diunduh tanggal : 05 Agustus 2017].

[3]. Mikrajab MA, Rachmawati T. Analisis kebijakan implementasi antenatal care terpadu Puskesmas di Kota Blitar. Puslitbang Humaniora dan Manajemen Kesehatan, Badan Litbang Kesehatan. 2015.

[4].Lincetto, O, MothebesoaneAnoh, S, Gomez, P. \& Munjanja, S. 2006. Antenatal care opportunities for Africa's newborns: practical data, policy and programmatic support for newborn care in Africa, South Africa: Cape Town. WHO, 5162. In: Mikrajab MA, Rachmawati T. Analisis kebijakan implementasi antenatal care terpadu a midwife who is unable to provide services health in accordance with the duties and functions will not be implemented optimally. The development of further research with a qualitative approach so that it can dig deeper and get more accurate information about factors related to the achievement of $\mathrm{K} 4$ coverage by the village midwife.

Puskesmas di Kota Blitar. Puslitbang Humaniora dan Manajemen Kesehatan, Badan Litbang Kesehatan. 2015.

[5]. Kemenkes RI. Permenkes No. 25 tahun 2014 tentang Upaya Kesehatan Anak. Tersedia pada: http://www.hukor.depkes.go.id [diakses 06 Agustus 2017].

[6].Kusumandari W. Bidan sebuah pendekatan midwifery of knowledge. Jilid 1. Yogyakarta: Nuh Medika; 2010. hlm. 41-44.

[7]. Rahma Erlina TL BK. faktorfaktor yang mempengaruhi ibu hamil terhadap kinjungan pemeriksaan kehamilan di Puskesmas rawat inap Bandar Lampung. Medical Journal of Lampung University. 2013.

[8]. Dinkes Kabupaten Banjar . Profil kesehatan kabupaten Banjar tahun 2014. Seksi Data dan Informasi Kesehatan 2015 April.

[9]. Gulo W. Metodologi Penelitian. 4 ed. Jakarta: PT. Grasindo; 2005.

[10]. Sumintono B,Widhiarso W Aplikasi model rasch untuk peneliti ilmu-ilmu sosial . Cetakan II Cimahi: Trim Komunikata Publishing House.2015.

[11]. Ida Parwati. 2014. Mempersiakan generasi emas 
melalui skrining laboratorium dalam proceeding Book Building Golden generation. bandung : FK- UNPAD.

[12]. Siagian. Manajemen Sumber Daya Manusia. Jakarta: Bumi Aksara. 2008.

[13]. Notoatmodjo S. Pendidikan dan perilaku kesehatan. Jakarta : PT. Rineka Cipta; 2010.

[14]. Handoko T, Hani. Manajemen Sumber daya Manusia, Yogyakarta: BPFE. 2007.

[15]. Siringo, A., Siti Saidah Nasution, 2012, Pengetahuan ibu hamil dan motivasi keluarga dalam pelaksanaan antenatal care di Puskesmas UjungBatu Riau, Jurnal Keperawatan Fakultas Keperawatan, UniversitasSumatera Utara.

[16]. Kemenkes RI. Laporan akuntabilitas kinerja. 2013.

[17].M. Wahyudin, Djumino.A. Analisis kepemimpinan dan motivasi terhadap kinerja pegawai pada kantor kesatuan Bangsa dan perlindungan masyarakat di Kabupaten Wonogiri.[document on internet]. Docstock on line. [diunduh 28 Agustus 2011]. Tersedia dari htt://www. docstock.com.

[18]. Mubarak W. Promosi Kesehatan. Jogjakarta : Graha Ilmu. 2007. Dalam: H Abu ADK, Kusumawati Y, Estu K Wardanai. Hubungan karakteristik bidan dengan mutu pelayanan antenatal care berdasarkan standar operasional. JKMA. 2015.

[19]. Ernawati. Evaluasi kinerja pelayanan antenatal antara puskesmas cakupan tinggi dengan puskesmas cakupan rendah menggunakan pendekatan balanced scorecard. Jurnal Managemen Pelayanan Kesehatan. 2009: 12(3).

[20]. Wawan, A. Teori \& Pengukuran pengetahuan, sikap dan perilaku manusia. Yogyakarta : Muha Medika: 2010. Dalam: H Abu ADK, Kusumawati Y, Estu K Wardanai. Hubungan karakteristik bidan dengan mutu pelayanan antenatal care berdasarkan standar operasional. JKMA. 2015. 